\title{
Crustal structures beneath the Saxonian Granulite Massif, the České středohoří and the Doupovské hory Mts. based on the depth-recursive tomography
}

\author{
Miroslav NOVOTNÝ ${ }^{*}$, Zuzana SKÁCELOVÁ2, Bedřich MLČOCH² \\ ${ }^{1}$ Geophysical Institute, Academy of Sciences of the Czech Republic, Bočni II/1401, 14131 Prague 4, Czech Republic; mn@ig.cas.cz \\ ${ }^{2}$ Czech Geological Survey, Klárov 3, 11821 Prague 1, Czech Republic \\ * Corresponding author
}

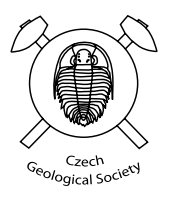

The P-wave velocity distribution, obtained recently by the depth-recursive tomography along the S01 refraction profile of the SUDETES 2003 seismic experiment, correlated fairly well with other geophysical results known in the area of the KTB deep drilling site. The $\mathrm{S} 01$ velocity model also provided a reliable velocity image of the upper and middle-crustal structures along the Eger Graben. In the present paper we will use the results of the depth-recursive tomography applied to the crossing S04 profile to derive a 3-D picture of structures near the S04 and S01 intersection.

The NW-SE trending S04 profile starts in the Saxonian Granulite Massif and intersects the Eger Graben in the region of Altenberg-Teplice Caldera. The depth-recursive tomography, applied to the S04 profile, also produced a velocity model allowing, together with the derived S01 velocities, a reliable 3-D interpretation down to the depths of 15-20 km. Besides the P-wave velocities, gravity, aeromagnetic and petrophysical data support the presented geological interpretation. Using the velocity and gravity data we identified the subsurface granitic and ultrabasic bodies in wider surroundings of the Saxothuringian and Teplá-Barrandian contact zone and also possible magmatic centers for the Teplice-Altenberg Caldera as well as for the Doupovské hory and the České středohoří volcanic complexes.

Keywords: Depth-recursive refraction tomography, SUDETES 2003 seismic profiles S04 and S01, Bohemian Massif, Saxonian Granulite Massif, Altenberg-Teplice Caldera, České středohoři and Doupovské hory volcanic complexes

Received: 29 April 2010; accepted: 10 September 2010; handling editor: J. Konopásek

\section{Introduction}

Two refraction profiles $\mathrm{S} 01$ and $\mathrm{S} 04$ were recorded in the Western Bohemia as a part of the recent international seismic experiment SUDETES 2003 (Grad et al. 2003). They intersect in the Eger Graben near the Altenberg-Teplice Caldera gravity minimum, southwest of Litoměrice (Fig. 1). The S01 profile starts near the KTB site, then follows the SW-NE oriented Eger Graben (Fig. 1) and further NE crosses the Elbe Zone and the geological structures in the Lusatian Complex. Recently, Grad et al. (2008) used the S01 wide-angle seismic data to derive a velocity model involving the whole crust. Based only on the distinct first breaks of refraction waves along the S01 line, Novotný et al. (2009) applied the DRTG method (Depth Recursive Tomography on Grid) to derive a P-wave velocity image of upper and middle crust yielding here a higher resolution. The DRTG inversion of the refraction first arrivals was performed using a regular network of refraction grid rays that allowed a statistical assessment of the resolution: the lateral sizes of the velocity anomalies to be resolved were derived depending on their depths, velocity excesses and desired confidence level. Thus, for the $68 \%$ confidence and $5 \%$ excess, we can resolve the velocity anomalies in the $\mathrm{S} 01$ pattern with the minimum size from 7.5 to $20 \mathrm{~km}$ depending on their depth positions from 0 to $20 \mathrm{~km}$ (see Novotný et al. 2009, fig. 10 and accompanying text). The S01 velocity features proved to be consistent with Vertical Seismic Profiling (VSP) and log measurements at the KTB site.

Profile S04 starts in the region of the Saxonian Granulite Massif, crosses the Krušne hory Mts, then the Eger Graben and continues SE across the boundaries of the main units in the Bohemian Massif (Saxothuringian, Teplá-Barrandian, Moldanubian and Moravian units) to the West Carpathians. Růžek et al. (2007) developed a special two-step inverse procedure for inverting the refracted $\mathrm{Pg}, \mathrm{Pn}$ and reflected $\mathrm{Pm}$ phases. They derived velocity models down to the Moho along eight refraction profiles from recent seismic experiments in the Bohemian Massif. Based on their error analyses, Růžek et al. (2007) considered the S04 and other obtained models reliable down to a $15 \mathrm{~km}$ depth, where only the velocity anomalies exceeding $5 \%$ can be reliably detected.

Within the range of $0-350 \mathrm{~km}$, the $\mathrm{S} 04$ seismic data were acquired in the most detailed average inter-shot and inter-station spacing of $34.5 \mathrm{~km}$ and $3 \mathrm{~km}$, respectively. Using the DRTG method only for the distinct first arrivals 


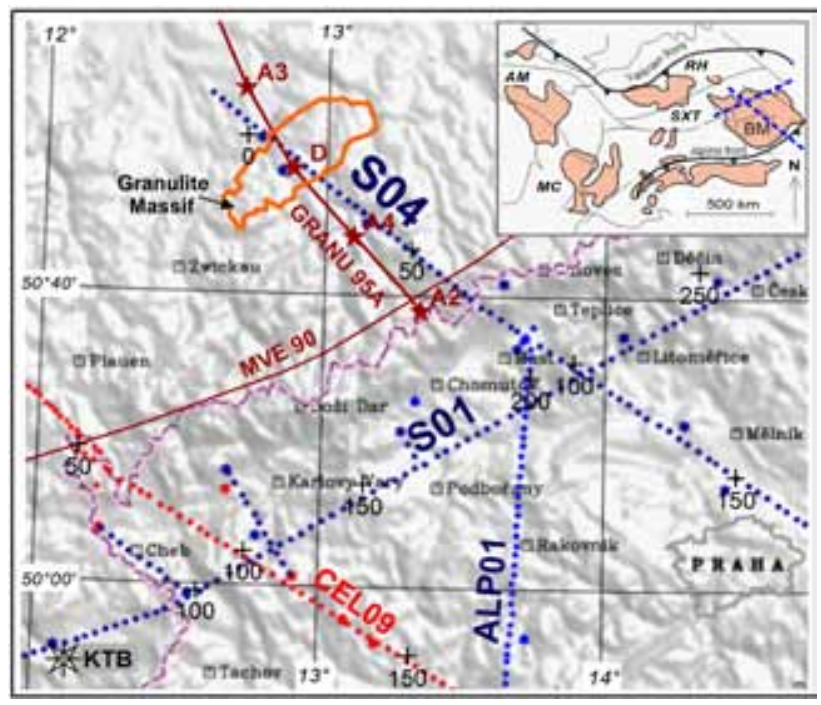

Fig. 1 The seismic profiles of the SUDETES 2003, ALP 2002, CELEBRATION 2000 refraction experiments (Guterch et al. 2003) and the DEKORP 3 and GRANU 95 projects in the Bohemian Massif. The circles and stars show the locations of the stations and shot points in the related seismic measurements. The ticks with a step of $50 \mathrm{~km}$ mark the distance scales along the individual profiles. The background topography is from the US Geological Survey TOPO 30 model by Švancara et al. (2005). Inset shows the position of S04 within the European Variscides. BM - Bohemian Massif, AM - Armorican Massif, MC Massif Central, SXT - Saxothuringian Zone, RH - Rhenohercynian Zone (adapted after Pitra et al. 1999).

of refraction waves in this range, a P-wave velocity image was obtained with the resolution comparable to that attained by DRTG tomography on the S01 profile. For the compared $68 \%$ confidence, the $5 \%$ velocity anomalies are resolvable in the S04 velocity pattern if their minimum lateral sizes amount $5-17 \mathrm{~km}$ at the depths of $0-6 \mathrm{~km}$ or $16-24 \mathrm{~km}$ at the depths of $12-15 \mathrm{~km}$. Velocity anomalies under $5 \%$ can be then also detected if their lateral sizes exceed the minimum limit specified for the desired confidence level. A peculiarity of the $\mathrm{S} 04$ refraction tomography is that there is the $6-11 \mathrm{~km}$ depth belt with frequent occurrence of low-velocity zones causing the zero statistical resolution. For more details see Novotný (in prep.).

The target of the SUDETES 2003 seismic experiment was to decipher the lithospheric structure of the Central Europe, especially in the Bohemian Massif as the easternmost part of the European Variscides. Relatively good quality of the S04 first arrivals allowed investigation of the shallower structures relevant for regional geology. The consistence and lateral resolution attained in both S04 and S01 velocity cross-sections near their junction allows delineation of crustal structures occurring under the Altenberg-Teplice Caldera (ATC) and the České středohoří Mts. Based on the presented P-wave velocity and gravity models and extensive borehole data in the region (e.g. Mlčoch and Konopásek 2010), a subsurface geological model along the S04 line is composed. The model involves partially the root zone of the Saxonian Granulite Massif, further the southwestern margin of ATC structures and the collision zone of the Saxothuringian and the Teplá-Barrandian units.

\section{Geological setting, gravity and magnetic image}

The S04 profile intersects the S01 profile near the contact of the Saxothuringian Zone (SXT) and the Teplá-Barrandian Unit (TBU) that were interpreted as the two major terranes of the Bohemian Massif - see e.g. Matte et al. (1990) and Fig. 2. The SW-NE trending contact zone is pronounced in the regional gravity image (Fig. 3). The striking horizontal gravity gradient observed between the negative (SXT) and the positive (TBU) gravity anomalies defines the Litoměrice Deep Fault (LDF) that is not demonstrated at the present surface (see e.g. Bucha and Blížkovský 1994).

The geophysical image of the studied area is complex. The most pronounced gravity minimum lies north of Bílina in the region of the Altenberg-Teplice Caldera. The S04 profile passes the southwestern flank of the ATC gravity minimum. An important role in the geophysical characteristics plays the Bílina Fault placed at the southeastern margin of the ATC gravity anomaly. Two local minima of Bouguer anomaly are pronounced in the north (Fig. 3). The former, located in the NW, reflects the Fláje Pluton (Fig. 2). The Fláje anomaly reaches its minimal value at the northern margin of the Most Basin that has the maximal thickness of sediments here. The latter, in the N-NE parts of the ATC, likely corresponds to a rather large accumulation of granites: Schellerhau Granite Complex and Cínovec-Krupka Composite Massif (e.g. Štemprok et al. 2003; Müller et al. 2005). On the other hand, a gravity high is caused by metabasites and ultramafic rocks cropping out in the Porta Bohemica area west of Litoměřice. The

Fig. 2 Geological sketch of the Early Carboniferous and older rocks with the profile network. Crystalline basement below the Late Paleozoic and younger strata after Mlčoch and Konopásek (2010) is shown in color. Geological units: SXT - Saxothuringian Zone, TBU - TepláBarrandian Unit, ATC - Altenberg-Teplice Caldera, LP - Louny Pluton, LSP - Lusatian Pluton, NEP - Nejdek-Eibenstock Pluton, SP - Smrčiny Pluton, FP - Fláje Pluton, TR - Teplice rhyolite, MLC - Mariánské Lázně Complex, EMLC - equivalent of the Mariánské Lázně Complex below the Doupovské hory Mts., LVRP - Lower Vltava River Pluton after Fediuk (2005), WN - Wildenfels nappe. FN - Frankenberg nappe. Faults: BF - Bílina Fault, CSF - České středohoří Fault, CHF - Chomutovka Fault, JF -Jáchymov Fault, KHF - Krušné hory Fault, LF - Liboc Fault, LSF - Lusatian Fault, SF - Střezov Fault, STF - Stráž Fault. 


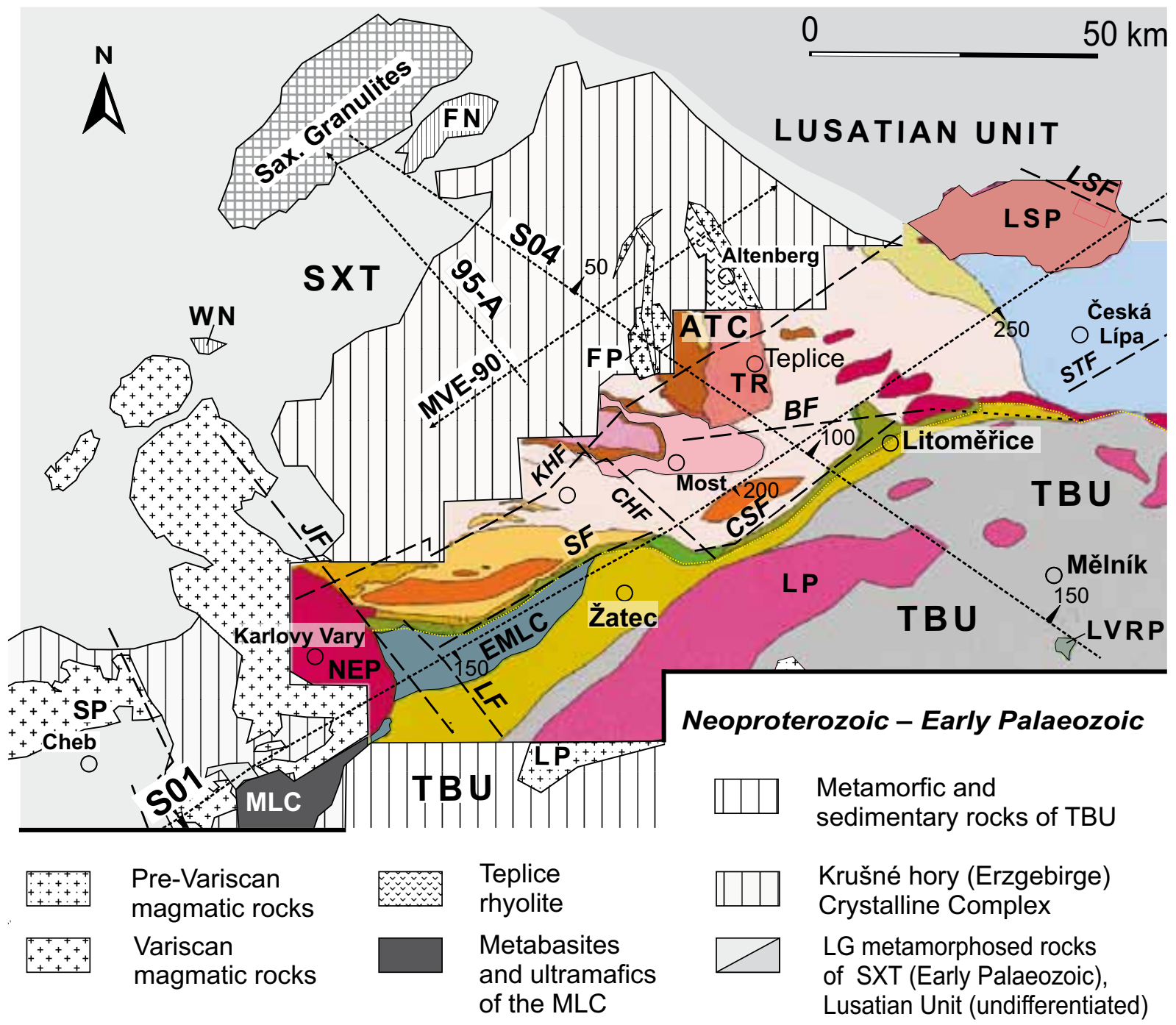

\section{Saxothuringian Zone}

\section{Lusatia}

\section{Teplá-Barrandian Unit}

Variscan

magmatic rocks

$\square$ orthogneiss

Pre-Variscan magmatic rocks

Lower VItava

River Pluton

orthogneiss,

metagranite

granulite

rhyolite

of Altenberg-

Teplice Caldera phyllite

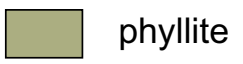

mica-schist

amphibolite

gneiss

paragneiss

metabasites and

ultramafics of the

MLC and EMLC phyllite,

greenschist

phyllite of Elbtal

-Schiefergebirge

(Early Palaeozoic)

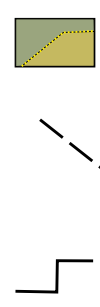

SXT-TBU

lithological

boundary

faults

extent of the crystalline

basement after Mlčoch

and Konopásek (2010) 


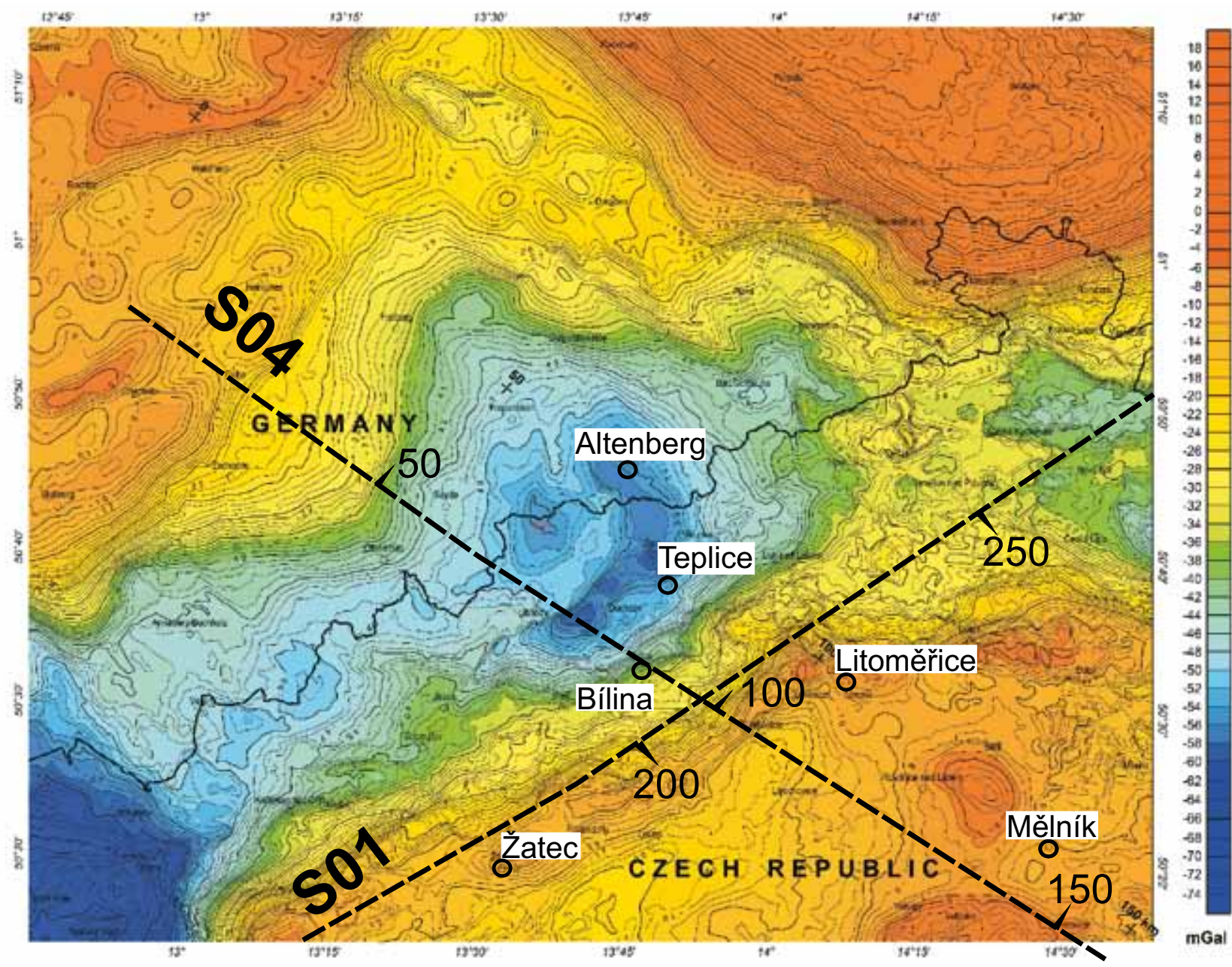

Fig. 3 Gravity map of the Altenberg-Teplice Caldera region with the profile network (after Sedlák et al. 2009).

TBU region, southeast of the LDF, is characterized by significantly increased values of the gravity field. The magnetic map (Šalanský 1995) shows distinct major positive anomalies occurring in both geological units near their contact. The small isolated positive anomalies are more intense and correspond to the Tertiary volcanic rocks of the České středohoří Mts. Švancara et al. (2005) derived the analytical continuation of magnetic anomalies for the half-space level of $10 \mathrm{~km}$. It indicates that the regional positive magnetic anomaly along the LDF may be caused by accumulation of mafic and ultramafic rocks at the depths greater than $5 \mathrm{~km}$.

\section{S04 and S01 cross-sections}

\subsection{S04 velocity pattern}

The S04 velocity model that will be interpreted together with the S01 cross-section is depicted in Fig. 4 and complemented by real geological observations. It is a part of the velocity model derived by Novotný (in prep.) for an extended distance range $(0-350 \mathrm{~km})$. We also refer to this work for the lateral resolution achieved by the DRTG method and the model ambiguity inherent to any refraction tomographic method if low-velocity zones are present. Refraction tomography cannot determine the velocities within such zones, i.e. in the regions with negative velocity depth gradient preventing refraction waves to return to the surface. The main advantage of the DRTG method is that it updates and verifies the derived velocity models for every grid node of the imaged model domain. In Fig. 4, the P-wave velocities are contoured in a $100 \mathrm{~m} \cdot \mathrm{s}^{-1}$ step. The grid nodes, where the model velocities were verified, are denoted by dots. The low-velocity zones (LVZs) with a weak or negative velocity gradient, occurring mostly in the $6-11 \mathrm{~km}$ depths, are not verified inside (no dots in grid nodes), but by the refraction grid rays crossing LVZs. They yielded the best fit for this model thanks to the involved LVZs. The same grid sampling $(\Delta x=5000 \mathrm{~m}$ and $\Delta z=500 \mathrm{~m})$ was used as in the case of the S01 model. 


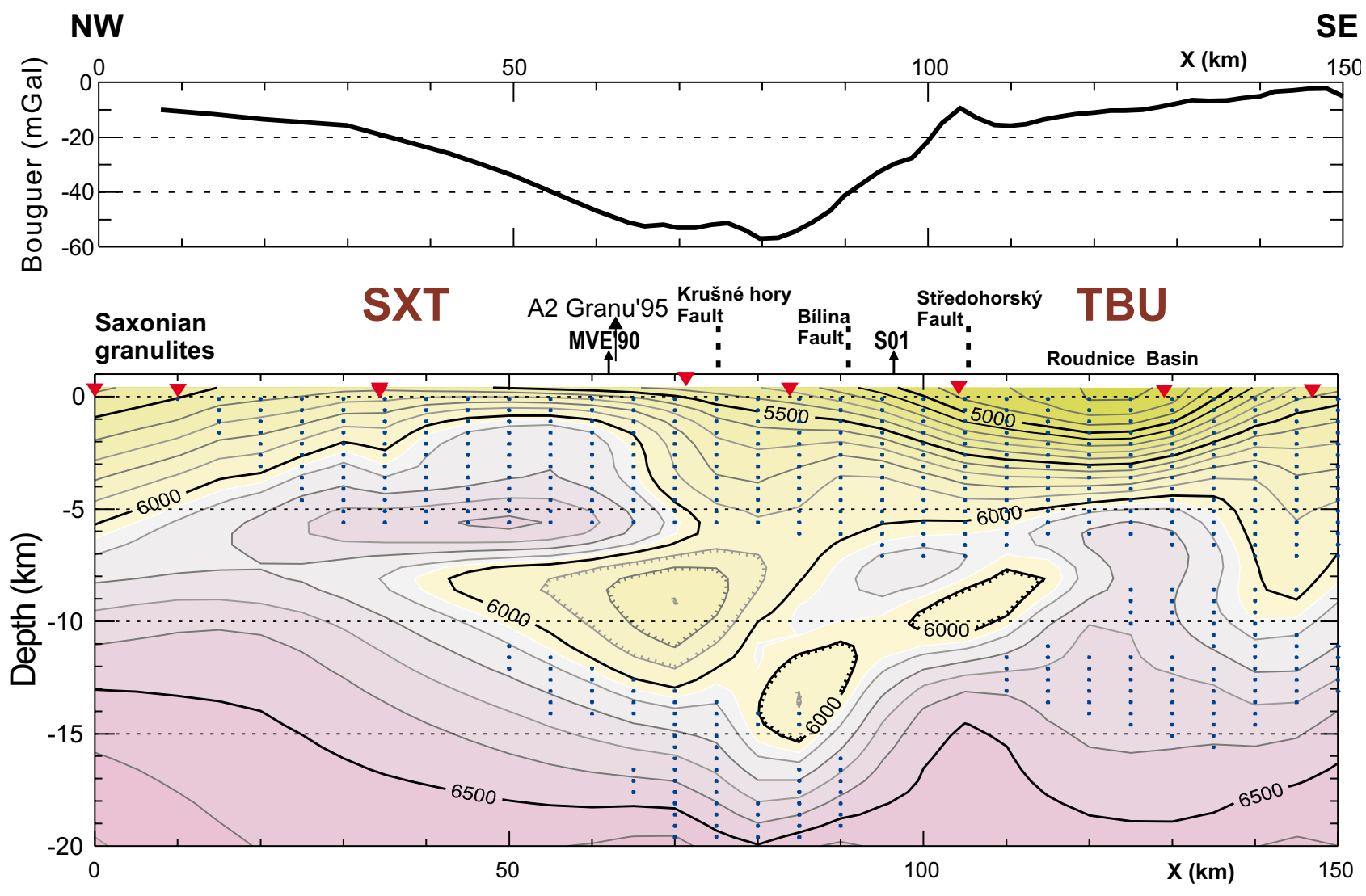

Fig. 4 Bouguer anomalies for a reduction density of $2.67 \mathrm{~g} . \mathrm{cm}^{-3}$ (top) and P-wave velocities along S04 profile contoured at the $100 \mathrm{~m} . \mathrm{s}^{-1}$ step. Inserted is the 6050 isovelocity - just colored. The dots denote the grid nodes verified by the refraction grid rays. Intersections with the profiles MVE-90 and S01 are marked. Triangles stand for the shot point positions at the S04 distance scale. SXT - Saxothuringian Zone, TBU - Teplá-Barrandian Unit.

The DRTG velocity features encountered in the $0-150$ $\mathrm{km}$ range are also confirmed by independent geophysical methods, namely by the inverse gravity modeling and by the forward ray-tracing modeling on two near collateral profiles. For inverse gravity modeling along the S04 line, we use the Bouguer gravity anomaly (top of Fig. 4) derived by Švancara et al. (2005) for the reduction density of $2.67 \mathrm{~g} . \mathrm{cm}^{-3}$.

Recently, Sedlák et al. (2009) studied the gravity response of igneous rocks in the southeastern Saxony and northwestern Bohemia. In a previous study aimed at the geothermal drilling near Litoměřice, Sedlák et al. (2007) derived a 2-D density model down to $12 \mathrm{~km}$ depth along a NW-SE trending profile that passed the geothermal borehole LT-1 located $13 \mathrm{~km} \mathrm{NNE}$ of the S04 line $(\mathrm{km}$ $\sim 105$ ). The densities and block interfaces inferred by the inverse gravity modeling near the LT-1 borehole reflected fairly well the blocky structure that is in accord with the S04 velocity pattern. In particular, they involve the minor HV (high-velocity) and LV (low-velocity) anomalies at the contact zone of the Saxothuringian and the TepláBarrandian units. Their deeper positions, if compared with the density model by Sedlák et al. (2007), are in agreement with the trend (dipping southwest) detected in the crossing S01 profile (see the S01 velocity pattern near the S04 intersection in Fig. 6). The gravity modeling performed directly along the $\mathrm{S} 04$ line is presented later, in Chapter 4.

The northwestern end of the S04 profile reaches the Saxonian Granulite Massif. This region was covered by several refraction and reflection profiles, performed within the framework of two seismic projects DEKORP 3/MVE 90 and GRANU 1995 - see DEKORP Research Group (1994) and Enderle et al. (1998). The DEKORP 3/MVE 90 surveyed the Variscan structures of the Rhenohercynian and the Saxothuringian zones while the GRANU 1995 seismic profiles targeted the Saxothuringian Zone and the Saxonian Granulite Massif. The reflection profile MVE-90 East was measured along the northwestern Czech border (Fig. 1). It intersects the S04 line at $\mathrm{km} \sim 61$. The DEKORP and GRANU seismic profiles provided basic data for the studies of the geological development of the Saxothuringian Zone (e.g. Krawczyk et al. 2000; Franke and Stein 2000).

The GRANU 95A seismic profile intersects the S04 line between the shot points A3 and D in the Saxonian Granulite Massif (Figs 1 and 5). It diverges under a low angle to the southeast related to the S04 line - its shot 

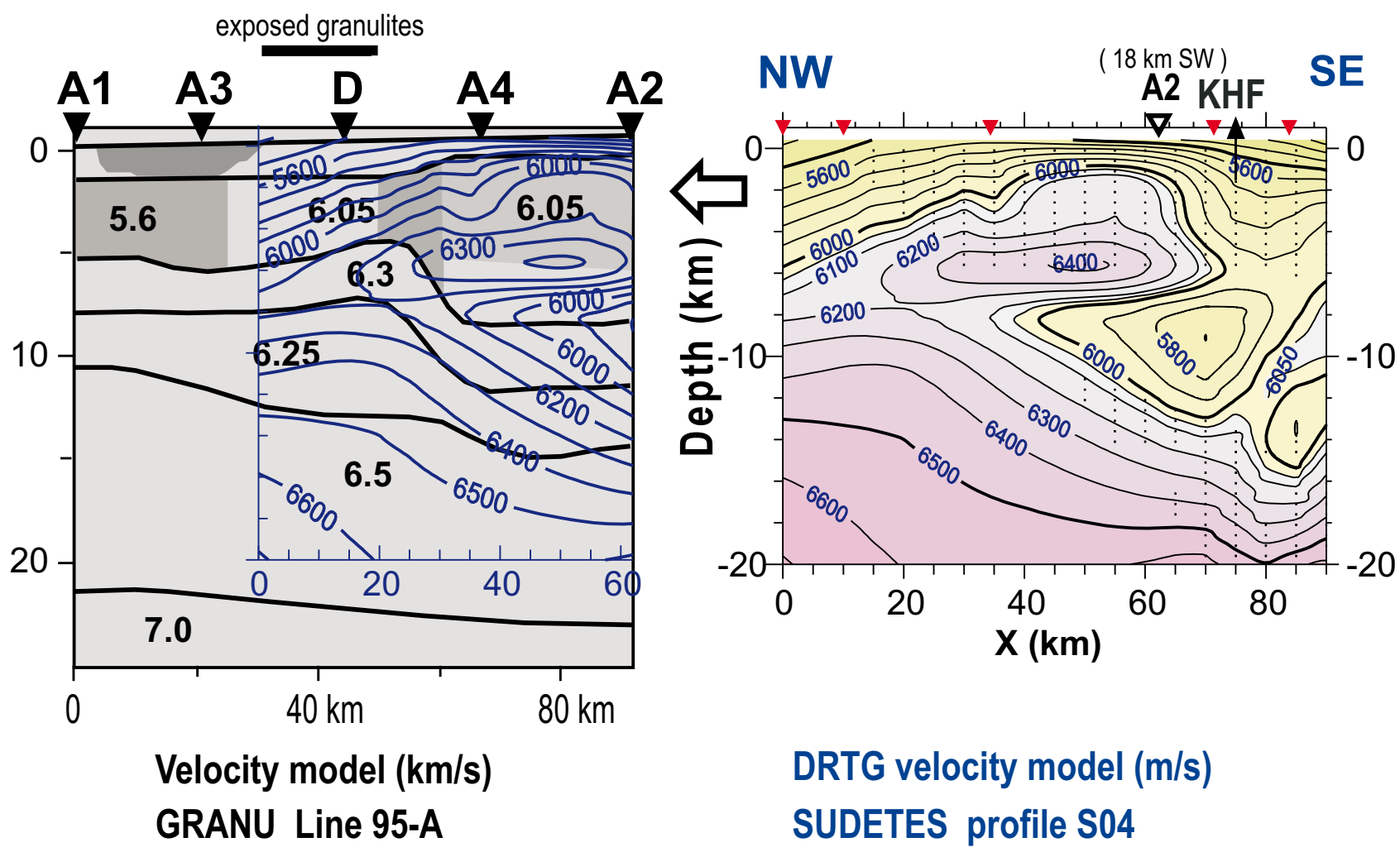

\section{DRTG velocity model $(\mathrm{m} / \mathrm{s})$ SUDETES profile S04}

Fig. 5 Comparison of the GRANU 95A and S04 velocity sections. The GRANU 95A model was adapted after Enderle et al. (1998). The GRANU shot point A2 is projected to the S04 distance scale at $\mathrm{km}$ 62, the profile intersection lies between the shot points A3 and D. KHF - Krušné hory Fault.

point A2 is placed at $\sim 18 \mathrm{~km}$ southwest of the S04 line. It is interesting to compare the overlapping parts of the S04 model and the GRANU 95A model derived by forward modeling (Enderle et al. 1998). Figure 5 presents the P-wave velocity distribution along the overlapping sections. The S04 profile intersects the 95-A line between the A3 and D shot points. The A2 shot point is located at the southeastern end of the 95-A line and is projected to $\mathrm{km} \sim 62$ of the S04 distance scale. Since the GRANU 95A model used a special (blocky) representation, it can be only partially compared with the regular S04 isovelocities as presented in Fig. 4. However, the basic features can be seen in both models: the HV body at $\sim 6 \mathrm{~km}$ depth and the underlying $\mathrm{LV}$ zone extending down to about $12 \mathrm{~km}$ depth below and southeast of the exposed granulites.

\subsection{S01 velocity pattern}

The S01 profile range of interest is depicted in Fig. 6. The curve of Bouguer anomalies was derived by Švancara et al. (2005) for the reduction density of $2.67 \mathrm{~g} . \mathrm{cm}^{-3}$. The $\mathrm{P}$-wave velocities are contoured at an interval of 100 $\mathrm{m} . \mathrm{s}^{-1}$ over the verified model nodes extending down to the $20 \mathrm{~km}$ depth. As expected, no verification by refraction grid rays was obtained directly in the low-velocity zones. However, their conservation by the DRTG imaging yielded better travel-time fits of refraction rays passing through. Thanks to the results of detailed exploration at and near the KTB site, the S01 velocity model was proved to be consistent with other geophysical and geological evidence, particularly with the log velocities down to $\sim 8 \mathrm{~km}$. We refer to Novotný et al. (2009) for the detailed derivation of the S01 velocity model by the DRTG method and its geological interpretation.

As the most striking velocity features in the investigated S01 range, we observe two extensive elevations of $6600-5900 \mathrm{~m} . \mathrm{s}^{-1}$ isovelocities under the Doupovské hory and the České středohoří volcanic complexes (Fig. 6). They obviously correspond to the velocity/density contrast of the ultramafic underplate which could have formed during the extensive volcanic activity related to the Eger Graben (Ulrych et al. 1999, 2002). The DHVC and CSVC represent two major centers of intra-plate alkaline volcanism in the Bohemian Massif active from the Late Cretaceous to Quaternary (Ulrych and Pivec 1997; Cajz et al. 2009). The intermediate depression down to $14 \mathrm{~km}$ corresponds to pre-Variscan granites forming the basement of the Žatec Basin (TBU) and of the Bílina Block in the Saxothuringian Zone. The subvertical trend of the $6100 \mathrm{~m} \cdot \mathrm{s}^{-1}$ isovelocity is interpreted as the northeastern margin of the Nejdek-Eibenstock Pluton at km 140 and the southwestern margin of the Lusatian Block at km 250 (Novotný et al. 2009). 
SW
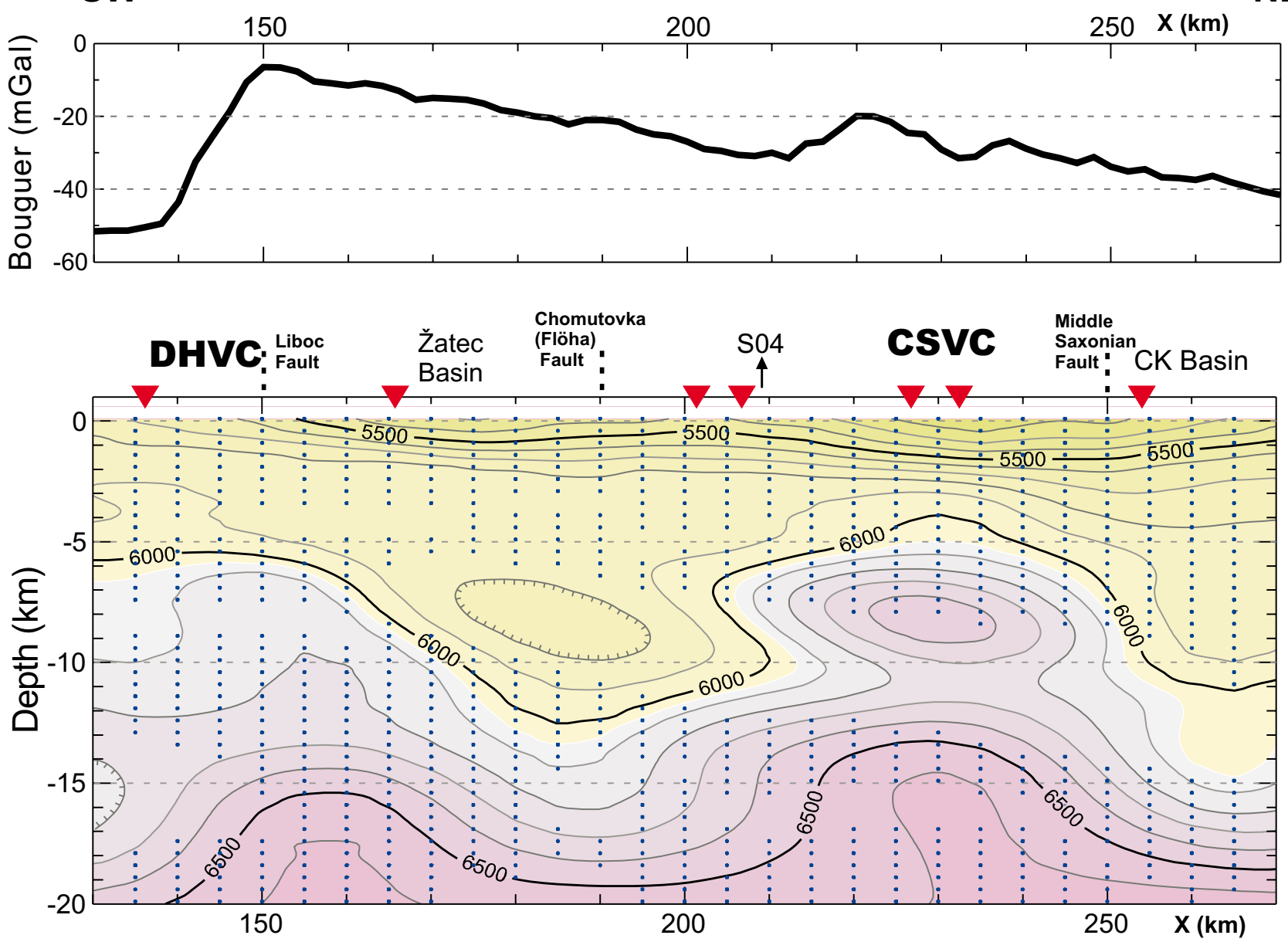

Fig. 6 The P-wave isovelocities at the $100 \mathrm{~m} \cdot \mathrm{s}^{-1}$ step along the $\mathrm{S} 01$ profile range of $130-270 \mathrm{~km}$. The grey color starts at the 6050 isovelocity. The Bouguer anomalies were derived for a reduction density of $2.67 \mathrm{~g} . \mathrm{cm}^{-3}$ (top). The dots denote the grid nodes verified by the refraction grid rays. The intersection with the S04 profile and the shot-point positions (triangles) are marked. Abbreviations: DHVC - Doupovské hory Volcanic Complex, CSVC - České středohoří Volcanic Complex, CK Basin - Česká Kamenice Basin.

The particular target of the following interpretation is the buried HV body that appears between 200-250 $\mathrm{km}$ or $90-140 \mathrm{~km}$ on the S01 or S04 distance scales, respectively.

\section{Interpretation of crossing velocity patterns}

The S01 profile in the $130-250 \mathrm{~km}$ range under investigation runs close to the contact of the Saxothuringian Zone with the Teplá-Barrandian Unit (Fig. 2). It crosses two volcanic complexes of the Doupovské hory and the České středohoří Mts. and at km 250 it enters the Lusatian Unit (Fig. 6). The S04 profile starts in the Saxonian Granulite Massif, passes the ATC structures near their southwestern margin, then intersects perpendicularly the contact between SXT and TBU and continues to the Late Paleozoic Roudnice sedimentary Basin hidden today be- low the Cretaceous sediments (Figs 2 and 7). As follows from the Bouguer anomaly curve presented in Fig. 4, the S04 range is chosen to involve a wider environment of the ATC gravity minimum. The S01 and S04 intersection is located in the Bílina Block that belongs to the SXT, $10 \mathrm{~km}$ NW of the SXT-TBU contact. Table 1 summarizes the physical properties of main encountered rock types.

\subsection{Geological model}

Figure 7 presents a geological sketch based on the S04 velocity model. In the $20-60 \mathrm{~km}$ range, a high-velocity layer $\left(6200-6400 \mathrm{~m} \cdot \mathrm{s}^{-1}\right)$ is located at depths of 4-7 km. Its occurrence is also confirmed by the forward modeling on the GRANU 95A refraction profile (Fig. 4). The underlaying low-velocity block $\left(5800-6000 \mathrm{~m} \cdot \mathrm{s}^{-1}\right)$ at depths of 7-10 km may correspond to metamorphosed granitic rocks of the Saxothuringian Zone, as the labo- 


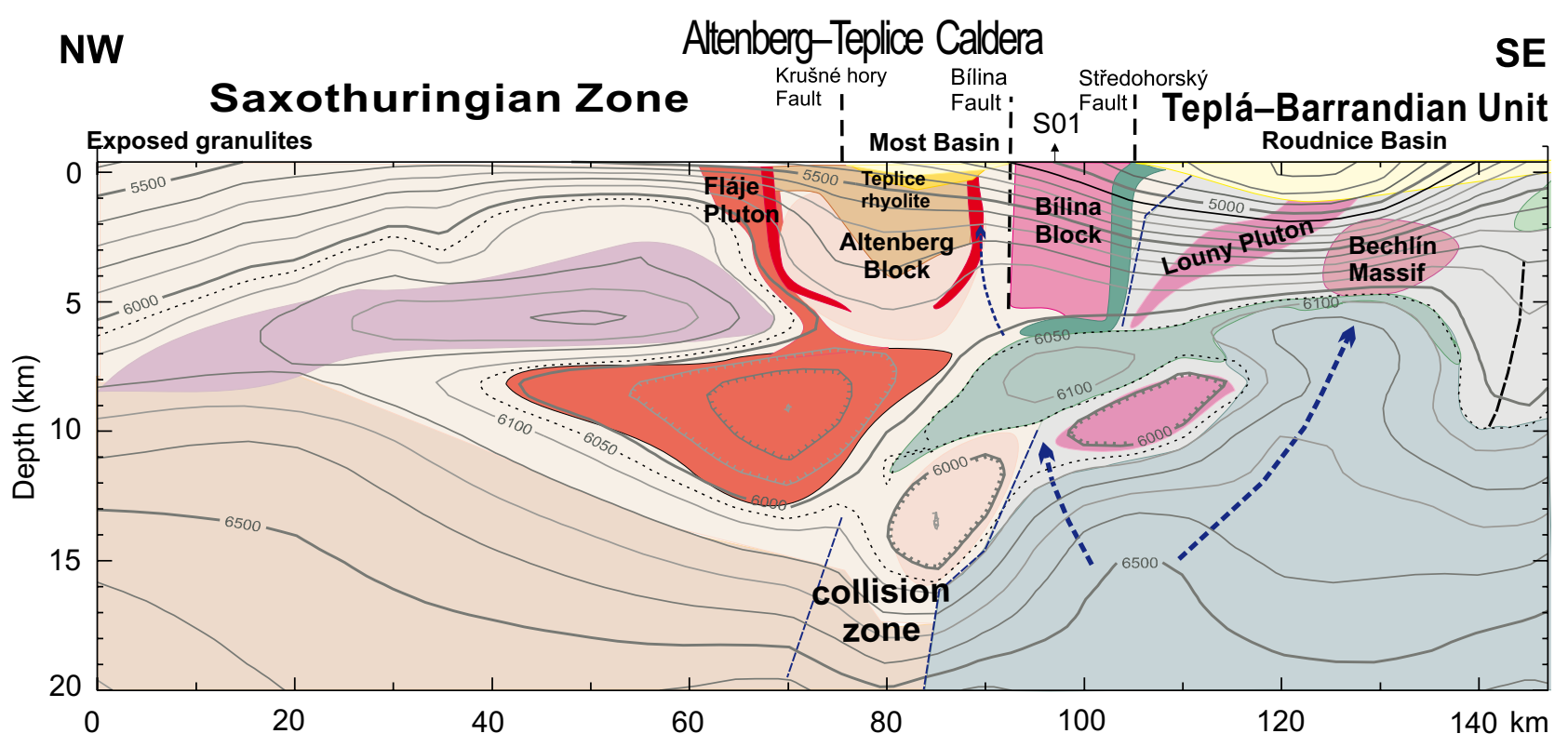

Fig. 7 Geological model inferred from the S04 isovelocities. Contour step $100 \mathrm{~m} \cdot \mathrm{s}^{-1}$.

ratory $\mathrm{P}$-wave velocities of orthogneisses are c. 5800$5900 \mathrm{~m} . \mathrm{s}^{-1}$. The P-wave isovelocity of $6200 \mathrm{~m} . \mathrm{s}^{-1}$ characterizes the basement, top boundary of which at the depths of $8-15 \mathrm{~km}$ dips steeply to the SE. The maximal depth of the basement $(\sim 15 \mathrm{~km})$ is reached at the collision zone between the Saxothuringian and Teplá-Barrandian units.

The S04 high and low-velocity anomalies at $\mathrm{km} 61$ (Fig. 4) correlate well with the high and low reflective zones of the crossing MVE-90 time section. The intersection is located at the geophone position $\sim 8240$ (i.e. $\mathrm{km}$ 362) northeast of the Flöha Zone in the Sayda orthogneiss block - see fig. 3.10, p. 704 in Behr and DEKORP Research Group B (1994). In particular, the granitic complex beneath the Sayda orthogneisses found in the MVE-90 cross-section for geophone positions of 8140-8410 reaches the Two-Way Time (TWT) down to $\sim 1 \mathrm{~s}$ which agrees fairly well with the top of the uppermost high-velocity anomaly in Fig. 3 near the MVE intersection. The transparent zone of decreased reflectivity in TWT of 2.2-4.7 s, i.e. at $\sim 6.6-15 \mathrm{~km}$ depth, corresponds to the intermediate LVZ. The deeper high-reflectivity zone starting from TWT $\sim 4.7$ s (i.e. from $\sim 15 \mathrm{~km}$ depth) corresponds to the basement at $6200 \mathrm{~m} . \mathrm{s}^{-1}$ reaching $\sim 15 \mathrm{~km}$ depth at the intersection $(\mathrm{km}$ 61) with the MVE-90 (Fig. 7). Note that the geological interpretation of MVE-90 time section (illustrated by the above-mentioned fig. 3.10 of Behr and DEKORP Research Group B 1994) has shown that the transparent zone extends over the Flöha Zone, as far as $12-17 \mathrm{~km}$ southwest of the S04-MVE intersection.

Further southeast (60-90 km along the profile), the S04 velocity pattern images the southwestern margin of the Altenberg-Teplice Caldera that represents the largest region of the Late Paleozoic acidic volcanism in the Bohemian Massif. Recent studies (e.g. Štemprok et al. 2003) distinguished two phases of felsic magmatism in this area. The Fláje Pluton represents an older intrusion, whereas the younger granitic magmatism is represented by a series of granitic intrusions (e.g. the CínovecKrupka Composite Massif) accompanying the Teplice rhyolite and the granite porphyry dykes, also referred to as Altenberg-Frauenstein microgranites.

Based on thermobarometric study of melt inclusions in quartz phenocrysts, Müller et al. (2005) deduced at least two distinct depth ranges of magma storage, namely at $6-13 \mathrm{~km}$ and $17-24 \mathrm{~km}$. The deep magma reservoir of the Eastern Erzgebirge Magmatic Complex was considered as a main source for the Teplice rhyolite, Schellerhau granite and granite porphyry (AltenbergFrauenstein microgranite). Except for the northern margin, the granitic Bílina Block is fringed by metabasites and ultramafic rocks that are exposed in the Porta Bohemica area (see the bedrock edition of the geological map by Mlčoch 1994). A narrow ultramafic rim of the Bílina Block is also indicated in the gravity field (Figs 5 and 8). In agreement with the S04 velocity features (Fig. 7) and the results of inverse gravity modeling (Fig. 8 ), the contact zone between the Saxothuringian and the Teplá-Barrandian units is located under the Bílina Block at depths of $5-10 \mathrm{~km}$. The collision zone generally dips to the northwest, which is in accord with the geological interpretation of this part of the SXT-TBU boundary by Mlčoch and Konopásek (2010). 


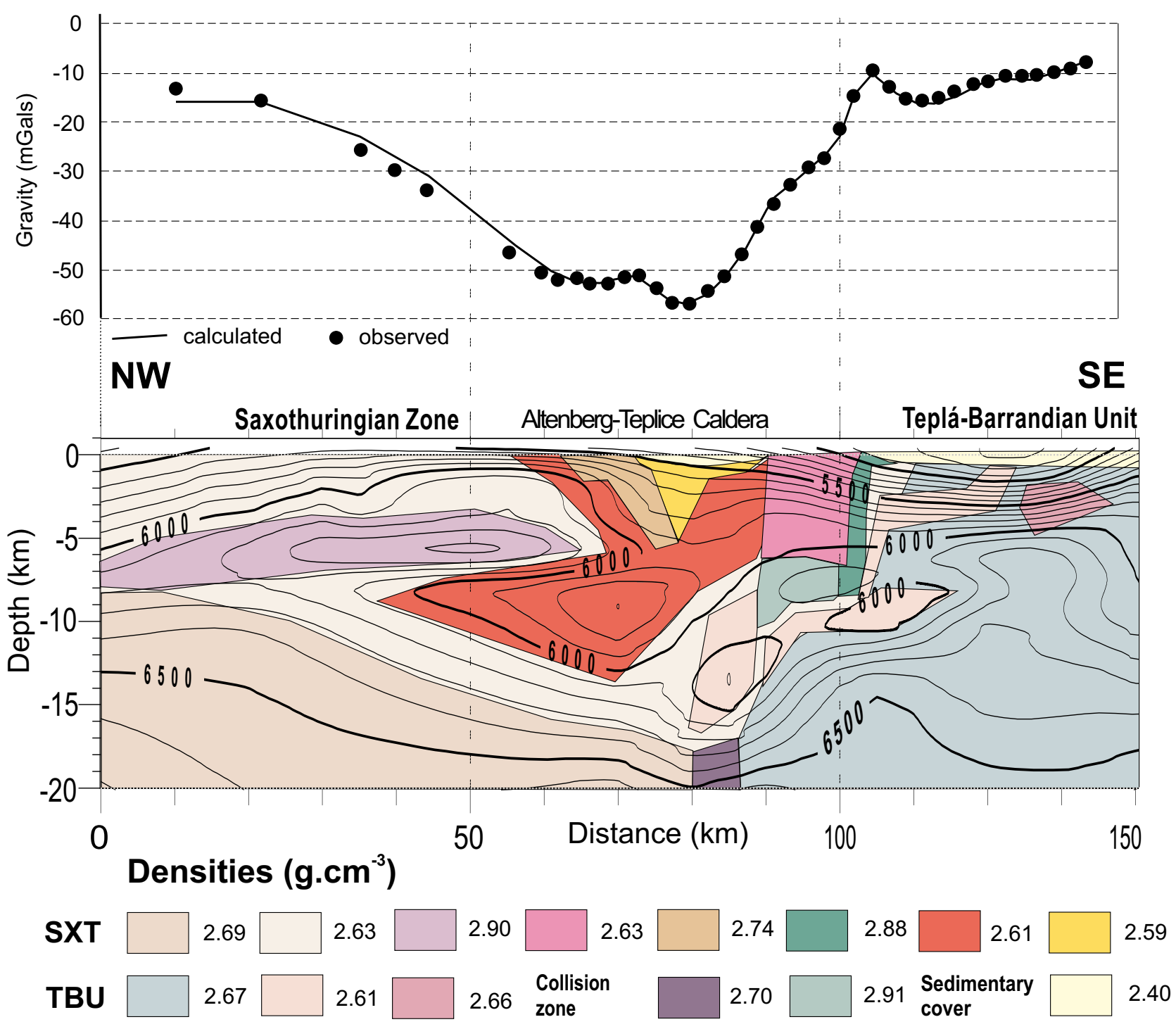

Fig. 8 S04 density model fitting the ATC gravity minimum. Block densities in $\mathrm{g} . \mathrm{cm}^{-3}$. Overlain are the S04 isovelocities $\left(\mathrm{km} . \mathrm{s}^{-1}\right)$.

\subsection{Density model}

The S04 velocity model and its correlation with the deep reflection MVE-90 profile and gravity data constrain the position and thickness of the ATC structures. Mlčoch and Skácelová (this volume) describe a shallow geological model of the ATC based on the borehole database and reflection seismic data. To verify the $\mathrm{P}$-wave velocities at the S04 cross-section we deduced a simple density model (Fig. 8) that fits the Bouguer anomaly along the S04 line near the ATC gravity minimum. The densities used for the single model blocks are in conformity with the physical properties (apparent bulk density $\mathrm{D}_{\mathrm{o}}$, mineralogical density $\mathrm{D}_{\mathrm{m}}$, porosity and velocity $\mathrm{Vp}-$ see Tab. 1) of the as- sumed rock types - granites and orthogneisses. At depths 10 to $12 \mathrm{~km}$, the density model involves the occurrence of rocks with low P-wave velocities (5500-6000 m.s $\mathrm{s}^{-1}$ ) and low densities of c. 2.62-2.63 g. $\mathrm{cm}^{-3}$. Similarly, the previous interpretation of MVE-90 transect (DEKORP 1999) estimated the thicknesses of the Fláje, Schellerhau and Sadisdorf granites to be 9-12 km and of the Teplice intrusion zone with the Altenberg granite porphyry dykes to $10-15 \mathrm{~km}$.

\subsection{Magmatic emplacement}

Generally, the velocity image best records the highdensity (mantle-derived) magmatic intrusions that show 
Tab. 1 Bulk $\left(D_{\mathrm{o}}\right)$ and mineralogical density $\left(\mathrm{D}_{\mathrm{m}}\right)$, directional P-wave velocities of representative rock types in the individual geological units

\begin{tabular}{|c|c|c|c|c|c|c|c|}
\hline \multirow{2}{*}{ Rock type } & \multirow{2}{*}{$\begin{array}{c}\text { Density D } \\
\text { g.cm }\end{array}$} & \multirow{2}{*}{$\begin{array}{l}\text { Density } \mathrm{D}_{\mathrm{m}} \\
\text { g.cm }^{-3}\end{array}$} & \multirow{2}{*}{$\begin{array}{c}\text { Porosity } \\
\%\end{array}$} & \multicolumn{3}{|c|}{ P-wave velocities $\left(\mathrm{m} . \mathrm{s}^{-1}\right)$} & \multirow{2}{*}{$\begin{array}{c}\text { Number } \\
\text { of samples }\end{array}$} \\
\hline & & & & mean & $\max$ & $\min$ & \\
\hline granite (Čistá-Jesenice Composite Pluton) & 2.63 & 2.64 & 0.8 & 5700 & - & - & 22 \\
\hline granodiorite (Čistá-Jesenice Composite Pluton) & 2.62 & 2.66 & 1.1 & 5900 & - & - & 76 \\
\hline Bechlín diorite (Čistá-Jesenice Composite Pluton) & 2.84 & 2.87 & 0.6 & 6400 & - & - & 128 \\
\hline Teplice rhyolite (Altenberg-Teplice Caldera) & 2.63 & 2.66 & 1.0 & 6200 & - & - & 18 \\
\hline granite (Cínovec-Krupka Composite Massif) & 2.60 & 2.64 & 1.1 & 6000 & - & - & 115 \\
\hline phyllite (Teplá-Barrandian Unit) & 2.72 & 2.76 & 1.4 & - & 6300 & 5200 & 10 \\
\hline metabasite (Teplá-Barrandian Unit) & 2.90 & 2.95 & 1.7 & 7400 & - & - & 26 \\
\hline orthogneiss (Saxothuringian Zone) & 2.59 & 2.66 & 2.6 & 5700 & - & - & 110 \\
\hline paragneiss (Saxothuringian Zone) & 2.66 & 2.73 & 2.6 & - & 6200 & 5400 & 92 \\
\hline amphibolite (Porta Bohemica, Saxothuringian Zone) & 2.86 & 2.92 & 1.9 & 6300 & - & - & 8 \\
\hline dark granulite (Saxothuringian Zone) & 2.87 & 2.92 & 1.5 & - & 6700 & 6000 & 5 \\
\hline light granulite (Saxothuringian Zone) & 2.63 & 2.67 & 0.9 & 5310 & - & - & 7 \\
\hline gabbro & 2.95 & 3.10 & 0.4 & 6500 & - & - & 4 \\
\hline pyroxene diorite & 3.10 & 3.10 & 0.5 & 6700 & - & - & 2 \\
\hline
\end{tabular}

a distinct density/velocity contrast against the surrounding lower density crustal rocks. Gravity differentiation in the ascending magmas causes a considerable decreasing velocity gradient along the magma ascent path or, more precisely, along the magmatic channels axes. The created contrast may persist after the solidification of magma and we can observe it, e.g., as positive P-wave velocity anomalies bound to these magma-ascent conduits.

Let us search such signatures near the ATC region in the middle crust. According to the lateral resolution achieved in the velocity sections, our analyses may document (multiphase) magmatic channels of regional scale, rather thousands than hundreds of meters wide, in dependence also on the persisting velocity contrasts.

Distinct elevations on the $6600-6300 \mathrm{~m} . \mathrm{s}^{-1}$ isovelocities at the depths of $15-13 \mathrm{~km}$ can be observed in both S04 and S01 sections at km 105 and 230, respectively (Figs 4 and 6). Their depth range corresponds to the deeper magma reservoir assumed by Müller et al. (2005) for the ATC volcanic region. Moreover, next velocity elevations on the $6000-5500 \mathrm{~m} \cdot \mathrm{s}^{-1}$ isovelocities can be traced at the S04 cross-section along a conduit aiming at the ATC region - see the assumed magma paths marked by arrows in Fig. 7.

The root path of magma is divided at $\sim 15 \mathrm{~km}$ depth into two branches: the northwestern one, leading towards the ATC, and the southeastern one, reaching as shallow level as $\sim 3 \mathrm{~km}$ near the Bechlín Massif (Figs 2, 7 and 8). At $85-130 \mathrm{~km}$, both branches create a magmatic body doming from 9 to $5 \mathrm{~km}$ depth at the $6050 \mathrm{~ms}^{-1}$ isovelocity (Fig. 4). This magmatic body in the S01 cross-section acquires a rather diapir-like shape - see the $6050 \mathrm{~ms}^{-1}$ isovelocity near the $\mathrm{S} 04$ intersection in the $\mathrm{S} 01$ velocity pattern (Fig. 6). It may correspond to the shallower ATC reservoir, whose existence was predicted by Müller et al.
(2005). According to the density model (Fig. 8) it could have supplied lighter, crust-derived melts in accord with the acidic volcanism observed in the ATC region. As follows from the S04 velocity image (Fig. 4), the northwestern conduit feeding the shallow magma reservoir is disrupted at $\sim 11 \mathrm{~km}$ depth. Then it continues into upper crust at $\mathrm{km} 90$ as marked by the elevations on the 6050 up to $5500 \mathrm{~ms}^{-1}$ isovelocities. The conspicuous interruption of this magma conduit at $\sim 11 \mathrm{~km}$ is likely caused by faulting in the collision zone (Fig. 7) and perhaps also by stoping processes, presumably in later phases of magmatic emplacement. The low-velocity host rocks in the crossing S01 profile were interpreted as pre-Variscan granites (Novotný et al. 2009).

The S04 velocity pattern delineates the upper-crustal conduit ( $\mathrm{km} \mathrm{85-95)}$ aiming at the ATC region located further to the NW. The elevations observed on the $6050-5500 \mathrm{~m} . \mathrm{s}^{-1}$ isovelocities trend upward along the Bílina Fault and mark a magma ascending path (Fig. 7). The Bílina Fault at km 90 separates the crystalline rocks of the Bílina Block from the Tertiary sediments of the Most Basin (see Fig. 2 for its trace in the crystalline basement). The magma channel confined to this fault zone is assumed to have supplied the crust-derived melts.

The S01 velocity pattern portrays the discussed magma reservoirs in the SW-NE transect (Fig. 6). Their upper boundary, marked by the $6050 \mathrm{~ms}^{-1}$ isovelocity, rises upward at $\mathrm{km} 230$. Here, the S01 velocity image reveals an upwelling under the Doupovské hory and České středohoří volcanic complexes - see, for instance, Ulrych et al. (1999) with Cajz et al. (2009). The local maxima of depicted 6000 and $5900 \mathrm{~ms}^{-1}$ isovelocities (Fig. 6) indicate magma conduits trending upwards into the volcanic regions. They may also be the sources of the ultramafic and mafic rocks (peridotite, serpentinite, 
pyroxene granulite and charnockite) found as xenoliths in the Tertiary volcanic rocks of the České středohoří Mts. (Opletal and Vrána 1989). Based on the S01 and S04 sections, the reservoir covers an extensive subsurface area of $40 \times 50 \mathrm{~km}^{2}$.

\section{Discussion and conclusions}

The Altenberg-Teplice Caldera region is located near the contact zone where the Saxothuringian rock assemblages were thrust over the Teplá-Barrandian Unit (Mlčoch and Konopásek 2010). The contact is represented by the gravity-defined Litoměřice Deep Fault (e.g. Št'ovíčková 1973) following the escarpments of the České středohoří and Střezov faults (Fig. 2). According to the geological map, an $8 \mathrm{~km}$ shift of the SXT-TBU contact is observed between the steep gravity gradient at the depth and the actual geological boundary (Mlčoch 2003; Mlčoch and Konopásek 2010). The boundary below the Bílina Block is documented in the velocity and density model (Fig. 8). Within the presented velocity and density models (Figs 7 and 8), the SXT-TBU collision zone can be further traced under the ATC region down to $\sim 20 \mathrm{~km}$ depth.

As documented by the S04 and S01 cross-sections, rather complex velocity image of the SXT-TBU collision zone probably results from several phases of magmatic activity and associated stoping processes affecting the host rocks and ascending melts during magmatic intrusions. The magmatic body discovered close to the S04-S01 intersection was interpreted as a shallower subvolcanic magmatic reservoir for the Altenberg-Teplice Caldera and the České středohoří Volcanic Complex. Contouring by the $6050 \mathrm{~ms}^{-1}$ isovelocity, it covers a subsurface area of c. $2000 \mathrm{~km}^{2}$ at $9-5 \mathrm{~km}$ below the surface. Another deeper reservoir demonstrated by a pronounced elevation on the $6500 \mathrm{~ms}^{-1}$ isovelocity at the $15-13 \mathrm{~km}$ depth is assumed to feed the shallower reservoir observed in 9-5 km depths. The depth ranges of both reservoirs are in agreement with the two levels of magma storage predicted by Müller et al. (2005) for Eastern Erzgebirge Volcano-Plutonic Complex. The feeding channels are clearly manifested in the S04 and S01 velocity images by the sequences of elevations on P-wave velocity contours whose maxima delineate the ascending paths of intruded magma.

The interpretation of the key velocity features obtained by the 2-D refraction tomography is neither comprehensive nor unique. The DRTG method however yielded relatively consistent results at the intersection of the $\mathrm{S} 04$ and S01 profiles. Figure 9 presents the depth velocity curves extracted from the DRTG models at their intersections: $96 \mathrm{~km}$ at S04 and $209 \mathrm{~km}$ at S01 distance scales. A fair correlation can be seen in the whole depth range. Particularly, both DRTG sections consistently imaged the

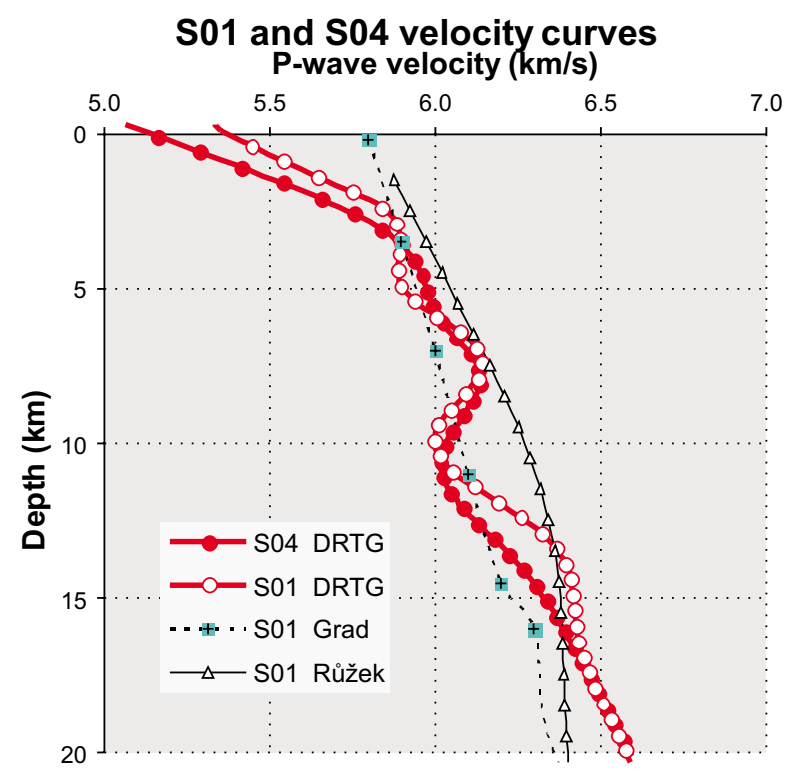

Fig. 9 P-wave velocities at the S01 and S04 intersection obtained by the DRTG and other methods - see text for details.

LVZ most profound at $10-12 \mathrm{~km}$ depths. The northwestern continuation of this LVZ was also found by forward ray-tracing in the GRANU 95A profile (Fig. 4) and is thus confirmed independently.

For the sake of completeness, Fig. 9 shows the results of the previous interpretations by Růžek et al. (2007) and Grad et al. (2008) derived from their final S01 models. Although the comparison of these models just for one $\mathrm{x}$-coordinate may not be representative on the whole, the sweeping out of the LVZ in both previous models can be inferred. For further discussion of low-velocity zones imaging by refraction tomography we refer to Novotný et al. (2009).

We believe that the consistent results of the DRTG tomography on both the S01 and S04 transects provide a reliable P-wave velocity image of magmatic centers below the Altenberg-Teplice Caldera and volcanic complexes of the Eger Graben.

The velocity model derived on the nearby GRANU95A profile was used for the geodynamic study of high-pressure granulites exhumation in the Saxothuringian Zone (Franke and Stein 2000). Since the S04 velocity pattern represents a southeastern continuation of the GRANU$95 \mathrm{~A}$ section, the presented velocity patterns allow extension of the geodynamic model toward the southeast, across the collision zone with the Teplá-Barrandian Unit.

Acknowledgments. This study was supported by the Project No A300460602 of the Grant Agency of the Academy of Sciences of the Czech Republic. The research was further financed by the Ministry of Education, Youth and Sports of the Czech Republic through 
the Research Centre 1M0554 "Advanced Remedial Technologies and Processes". The acquisition of the used $\mathrm{S} 01$ and $\mathrm{S} 04$ seismic data within the SUDETES 2003 Refraction Experiment were supported by the Research Project No 630/3/02 funded by the Ministry of Environment of the Czech Republic. The authors are grateful to O. Novotný, O. Krentz and R. Keller for their careful reviews, which contributed to improvement of this paper. Our thanks also belong to V. Janoušek and J. Konopásek for their thorough editorial work and useful critical comments.

\section{References}

Bucha V, BližKovskÝ M eds (1994) Crustal Structure of the Bohemian Massif and West Carpathians. Academia, Prague and Springer-Verlag, Berlin, pp 174-177

Cajz V, Rapprich V, Erban V, Pécskay Z, Radoñ M (2009) Late Miocene volcanic activity in the České středohoří Mountains (Ohře/Eger Graben, northern Bohemia). Geol Carpath 60: 519-533

Behr HJ and DEKORP Research Group B (1994) Crustal structure of the Saxothuringian Zone: results of the deep seismic profile MVE-90 (East). Z geol Wiss 22: 647-769

DeKorP and Orogenic Processes Research Groups, KRAWCZYK CM CORRESPONDENT (1999) Structure of the Saxothuringian granulites: geological and geophysical constraints on the exhumation of high-pressure/hightemperature rocks in the mid-European Variscan belt. Tectonics 18: 756-773

Enderle U, Schuster K, Prodehl C, Schulze A, Bribach J (1998) The refraction seismic experiment GRANU95 in the Saxothuringian belt, SE-Germany. Geophys J Int 133: $245-259$

Fediuk F (2005) The Lower Vltava River Pluton: a semihidden intrusive complex in Neoproterozoic at the northern outskirts of Prague, Central Bohemia. J Czech Geol Soc 50: 71-78

Franke W, Stein E (2000) Exhumation of high-grade rocks in the Saxo-Thuringian belt: geological constraints and geodynamical concept. In: Franke W, HAAK V, ONCKEN O, TANNER D (eds) Orogenic Processes: Quantification and Modelling in the Variscan Belt. Geological Society London Special Publications 179: 337-354

Grad M, Špičćk A, Keller GR, Guterch A, Brož M, BRÜCKL E, Hegedüs E (2003) SUDETES 2003 seismic experiment. Stud Geophys Geod 47: 681-689

Grad M, Guterch A, Mazur S, Keller GR, Špičćk A, HRuBCovÁ P, GeISSLER WH (2008) Lithospheric structure of the Bohemian Massif and adjacent Variscan belt in central Europe based on profile S01 from the SUDETES 2003 experiment. J Geophys Res 113: B10304, DOI: 10.1029/2007JB005497.
Guterch A, Grad M, Špičák A, Brückl E, Hegedüs E, Keller GR, Тнуво H (2003) An overview of recent seismic refraction experiments in central Europe. Stud Geophys Geod 47: 651-657

Krawczyk CM, Stein E, Choi S, Oettinger G, Schuster K, Götze HJ, Haak V, Oncken O, Prodehl C, Schulze A (2000) Geophysical constraints on exhumation mechanisms of high-pressure rocks: the Saxo-Thuringian case between the Franconian Line and Elbe Zone. In: FrANKE W, HaAk V, Oncken O, Tanner D (eds) Orogenic Processes: Quantification and Modelling in the Variscan Belt. Geological Society London Special Publications 179: 303-322

Matte P, Maluski H, Rajlich P, Franke W (1990) Terrane boundaries in the Bohemian Massif: result of large-scale Variscan shearing. Tectonophysics 177: 151-170

MLČOCH B (1994) The geological structure of the crystalline basement below the North Bohemian brown coal Basin. KTB Report 94 (3): 39-46

MLČOCH B (2003) Character of the contact between the Saxothuringian and Teplá-Barrandian Unit. Geolines 16: 75

MlČoch B, KonopáseK J (2010) Pre-late Carboniferous geology along the contact of the Saxothuringian and Teplá-Barrandian zones in the area covered by younger sediments and volcanics (western Bohemian Massif, Czech Republic). J Geosci 55: 81-94

MLČOCH B, SKÁCELOVÁ Z (2010) Geometry of the AltenbergTeplice Caldera revealed by the borehole and seismic data in its Czech part. J Geosci 55: 217-229

Müller A, Breiter K, Seltmann R, Pécskay Z (2005) Quartz and feldspar zoning in the eastern Erzgebirge volcano-plutonic complex (Germany, Czech Republic): evidence of multiple magma mixing. Lithos 80: 201-227

Novotný M (in prep.) P-wave velocity image of Bohemian Massif at the $\mathrm{S} 04$ transect. To be submitted.

Novotný M, Skácelová Z, Mrlina J, Mlčoch B, RưŽž B (2009) Depth-recursive tomography along the Eger Rift using the S01 profile refraction data: tested at the KTB super drilling hole, structural interpretation supported by magnetic, gravity and petrophysical data. Surv Geophys 30: $561-600$

Opletal M, VRÁnA S (1989) Charnockite xenoliths in the Tertiary volcanites of the České středohoři Mts., northern Bohemia. Sbor geol věd, Geol 44: 51-78 (in Czech)

Pitra P, Burg JP, Guiraud M (1999) Late Variscan strikeslip tectonics between the Teplá-Barrandian and Moldanubian terranes (Czech Bohemian Massif). J Geol Soc, London 156: 1003-1020

Rưžek B, Hrubcová P, Novotný M, ŠpičÁk A, Karousová $\mathrm{O}$ (2007) Inversion of travel times obtained during active seismic refraction experiments CELEBRATION 2000, ALP 2002 and SUDETES 2003. Stud Geophys Geod 51: $141-164$ 
SedLÁk J, Gnojek I, Zabadal S (2007) Zhodnocení anomálií gravitačního a magnetického pole v okolí vrtu PVGT LT-1. Assessment of gravity and magnetic anomalies near the PVGT LT-1 borehole. Unpublished manuscript, Geomedia Ltd., Prague and Miligal Ltd., Brno, (in Czech)

Sedlák J, Gnojek I, Zabadal S, Scheibe R, Zabadal $\mathrm{S}$ (2009) Gravity response of igneous rocks in the northwestern part of the Bohemian Massif. J Geosci 54: 325-342

ŠAlansKÝ K (1995) Magnetic map of the Czech Republic 1:500 000. Czech Geological Survey, Prague

ŠTemprok M, Holub FV, NovÁk JK (2003) Multiple magmatic pulses of the Eastern Volcano-Plutonic Complex, Krušné hory/Erzgebirge Batholith, and their phosphorus contents. Bull Geosci 78: 277-296

ŠŤovíčKovÁ N (1973) Hlubinná zlomová tektonika a její vztah k endogenním geologickým procesům. Deep fault tectonics and their relation to endogenous processes. Academia, Prague, pp 1-198 (in Czech)

Švancara J , ŠpaČek P, Hubatka F (2005) Geophysical image of regional geological structures and verification of crustal velocity models. In: NovotnÝ M (ed) SLICESeismic Lithospheric Investigation of Central Europe (Chapter 3). Unpublished final report, Czech Geological Survey-Geofond, Prague, pp 1-215 (in Czech)

Ulrych J, Pivec E (1997) Age-related contrasting alkaline volcanic series in North Bohemia. Chem Erde 57: 311-336

Ulrych J, Pivec E, Lang M, Balogh K, Kropáček V (1999) Cenozoic intraplate volcanic rock series of the Bohemian Massif: a review. Geolines 9: 123-135

Ulrych J, Svobodová J, Balogh K (2002) The source of Cenozoic volcanism in the České středohoří Mts., Bohemian Massif. Neu Jb Mineral, Abh 177: 133-162 
